\title{
COGNITIVE SCIENCES AND HUMAN DEVELOPMENT
}

\section{Padlet for Project-based Learning in an Entrepreneurship Course}

\author{
Dency Flenny Gawin* \\ Faculty of Resource Science and Technology, Universiti Malaysia Sarawak, 94300 Kota \\ Samarahan, Sarawak, Malaysia
}

\begin{abstract}
Padlet is a collaborative online tool that is widely used to complement online learning. This study investigates students' perception of using Padlet while executing project-based learning activities in the learning of entrepreneurship content and skills. Participants were assigned to use Padlet to facilitate remote group work discussions. Once the activities were completed, they filled out an online survey to capture their opinions and perceptions of the use of Padlet in their respective projects. The quantitative findings revealed that more than half of the participants agreed that Padlet is a useful online tool to support project-based learning activities. They also agreed Padlet can be used to nurture students' soft skills. Less than half still wanted to use Padlet if their internet connections were reliable. However, the rest were unsure of continuing using Padlet, and they indicated a preference to use other online tools. A few factors were identified to have also influenced the correlation between Padlet usage and assignments. Based on qualitative findings, although Padlet was viewed as a great collaborative tool supporting project-based learning activities in entrepreneurship education, it must be used with other online tools to overcome its technical shortcomings. Hence, modifying pedagogical strategies shall also be considered for making students participate actively in online discussion. In future, an in-depth investigation should focus on understanding the effectiveness of Padlet in entrepreneurship education in post-pandemic scenarios.
\end{abstract}

Keywords: project-based learning, entrepreneurship education, covid-19, Padlet

ARTICLE INFO

Email address: agdflenny@unimas.my (Dency Flenny Gawin)

*Corresponding author https://doi.org/10.33736/jcshd.3329.2021

e-ISSN: 2550-1623

Manuscript received: 25 April 2021; Accepted: 24 August 2021; Date of publication: 25 September 2021

Copyright: This is an open-access article distributed under the terms of the CC-BY-NC-SA (Creative Commons Attribution-NonCommercial-ShareAlike 4.0 International License), which permits unrestricted use, distribution, and reproduction in any medium, for non-commercial purposes, provided the original work of the author(s) is properly cited. 


\section{INTRODUCTION}

Entrepreneurship is said to have created many job opportunities and, at the same time, stimulate economic and social development in many countries (Matlay, 2005; Hebert \& Link, 2009; AbuSaifan, 2012; Ahmad \& Xavier, 2012). Realising the significance of entrepreneurship education in supporting entrepreneurial and social-economy development, the Ministry of Higher Education Malaysia has taken the initiative by requiring all students in the country's 20 public universities to participate in the entrepreneurship course and programmes starting in 2015. The idea behind the initiative was to inculcate entrepreneurial mindsets and behaviours into all students. The initiative was expected to produce at least five per cent of young graduate entrepreneurs by 2020 (Harian, 2006).

For entrepreneurship education to be more effective, it shall be linked to experiential learning (Kolb, 1984), entrepreneurial training (Gibb, 1999), work-related learning (Dwerryhouse, 2001) and action-learning (Smith, 2001). Project-based learning can also be integrated into entrepreneurship education programs (Botha, 2010). Project-based learning is a comprehensive teaching-learning method in which students will work in teams to develop and pursue solutions to problems or challenges by asking and refining questions, debating ideas, designing plans and experiments, communicating their ideas and results to others, and producing artefacts (Blumenfeld et al., 1991, Botha, 2010). The designated projects are primarily student-directed, which means that the instructors play their part as facilitators, while the students must engage in active learning (Frank et al., 2003). Integrating project-based learning in entrepreneurship education programmes is also a way to help students develop their "soft skills" in a setting like those skills that will eventually be used (Jamaluddin et al., 2019; Musa et al., 2012). These can let students work in a team environment and interact with people outside of their classrooms while executing entrepreneurial and business activities.

Before the Covid-19 pandemic, most teaching and learning were carried out physically in classroom settings. However, all of that changed when the pandemic started in March 2020. Instructors and students had to shift from face-to-face to online instructions for all courses rapidly. It is anticipated that instructors need to modify their existing teaching methods by integrating more digital technology, whether apps, virtual tutoring, video conferencing tools, or online learning software. Using these technological tools in education, instructors can shift their teaching and learning activities from teacher-centred to student-centred models (Fageeh, 2001). The shift from passive to active learning is promised to develop students' autonomy in learning via project-based, problem-based, task-based, case-based, or challenge-based learning approaches (Samaranayake, 2020). One digital technology tool commonly used in virtual classrooms during the Covid-19 crisis is Padlet (Ghazali \& Anuar, 2020; Othman, 2020; Rethinasamy \& Ramanair, 2020; Aneros, 2020). Before the pandemic, Padlet has already been widely used by many instructors in many educational institutions to engage with their students in the classrooms (Weller, 2013).

Padlet (www.padlet.com) is a collaborative "online bulletin board" accessible from many devices such as computers or smartphones. It is a versatile and flexible digital tool, which users can create limitless walls and invite others to collaborate on their walls (Zhi \& Su, 2015). Users can upload any content such as texts, images, documents, video files, audio clips and links on their walls which 
can be shared with others in several ways. With these features, instructors can integrate Padlet into their courses or subjects by creating interactive activities such as brainstorming, discussions and other engaging remote activities (Stannard, 2015). These activities will allow students to investigate and learn from their classmates' or team members responses (Fuchs, 2014), thus promoting positive learning experiences as well as activating more collaboration and engagement between them (Korkealetho \& Siklander, 2018). In addition, educators can use Padlet to enhance reflection opportunities for their students (Delacruz et al., 2014). Indeed, the application of Padlet in teaching and learning activities can improve students' soft skills (DeWitt et al., 2015; Scager et al., 2016; Rathakrishnan et al., 2018; Nadeem, 2019) such as adaptability, collaboration, leadership, empathy, team building and communications. It is interesting to decrease the knowledge gap by investigating the effectiveness of using the Padlet during the pandemic, where online learning is the only mode to reach students.

This study investigates students' perceptions of using Padlet while executing project-based learning activities in a university-level entrepreneurship course that was taught fully online. The study also aims to understand the impact of Padlet use in improving students' soft skills as they learn the contents and skills of Entrepreneurship.

This study attempts to answer the following research questions:

1. What are students' perceptions of Padlet as an online tool for learner engagement and collaboration?

2. What are students' perceptions of Padlet as an online tool for improving students' soft skills?

\section{METHODOLOGY}

The study was conducted for four months at a public university in Malaysia. The course was a two-credit entrepreneurship course opened to all first-year students at the faculty. The main objectives of this course are to expose students to the basics of entrepreneurial and business activities with an emphasis on the establishment and business startup. Besides, they will learn the fundamental principles of business operations such as business idea generation, preparation of a business plan, rules and laws about business activities, basic accounting management, marketing and supporting services.

The experimental study employed both quantitative and qualitative research designs (Figure 1). The total number of students taking part in this experiment was 88 students. They were divided into eight groups, with each group would have 11 team members. Before starting their online project, the instructor would teach students how to use Padlet by participating in two synchronous activities and sharing a few YouTube tutorials for them to do self-study.

After the students become familiar with the features of Padlet, they were asked to use four Padlet walls for 1) idea validation survey, 2) business model canvas (BMC), 3) financial planning and business pitching, and 4) business portfolio. These four Padlet walls would be used as examples to create their group Padlet walls (Figure 2). During the experiment, students were given the 
autonomy to manage their Padlet walls. They were encouraged to conduct online chat activities and upload relevant content (e.g., videos, links, articles, images) on their Padlet walls (Figure 3). The students were also required to invite the course instructor into their Padlet walls. The instructor plays the role of an online Padlet facilitator to provide guidance, if needed, anytime and anywhere. In addition, the instructor would check the frequency and quality of participation in Padlet by giving a score on the quantity and depth of discussions captured on the walls. The students' participation on Padlet walls were continually shared with other students to ensure the students actively use the discussion materials presented by all groups. All participation scores are added to the course assignments and pitching presentations.

At the end of the course, participants completed an online survey (at week 13) after submitting their final written assignments. The online survey was carried out using Google Forms. Students were asked to evaluate and give their opinions on their project-based learning experience using Padlet as a tool for collaboration. The online survey comprised 21 questions, one of which was an open-ended question. The questionnaire was constructed based on variables identified by Aneros and Herniwati (2020), Anwar et al. (2019), and Nadeem (2019). A Likert scale approach was used for 16 closed-ended questions (refer to Table 1-4). Three dichotomous (yes and no option) and one trichotomy (yes, no, maybe option) closed-ended questions required the students to determine if they found the usage of Padlet relevant for their remote learning journey (Table 1). All the closedopen questions were supplemented as the quantitative data. The data were then compared in the

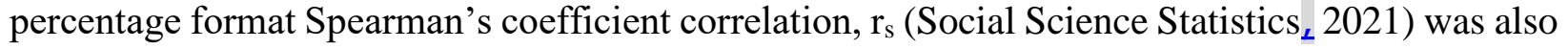
applied to see if there is a correlation between all 16 Likert scale closed-ended questions. The Correlation is a measure of the strength of the relationship between two combination variables: strongly disagree (SD) + disagree (D) options and agree (A) + strongly agree (SA) options. Spearman's online calculator was used to measure the relationship. The open-ended item was linked to one of the close-ended questions (Table 1, Item 3), in which students were required to elaborate on the reasons for choosing other learning and engagement tools instead of Padlet. 


\section{The Steps in Research}

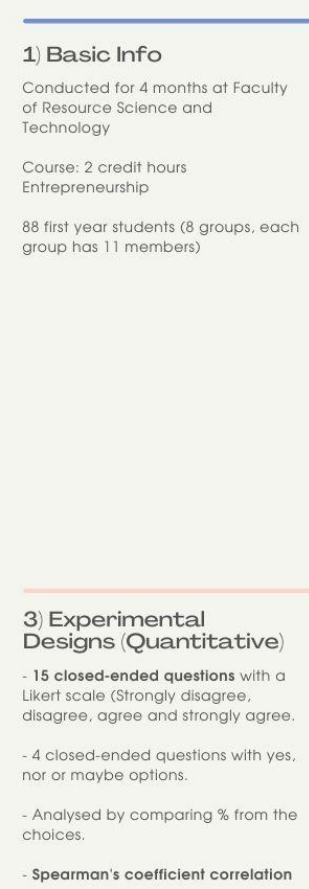

-Spearman's coefficient correlation

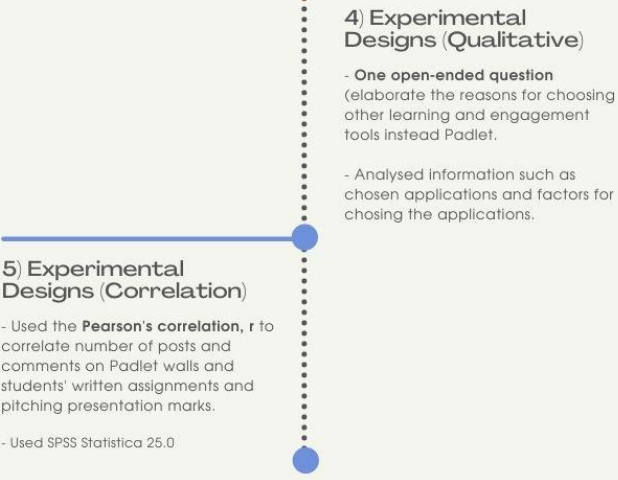

2) Activities

a. Students created 4 brainstorming Padlet walls

) Idea validation survey Business model canvas (BMC) pitching

4) Business portfolio

b. Using the walls to conduct online chat and upload relevant posts.

- Students' participations were calculated based on how many

c. suade

proposal presentations (pitching)

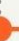

4) Experimental signs Qualitative) 列

such as chosen applications and factors for chosing the applications. presentation marks.

\section{SUMMARIZED METHODS USED}

$$
\text { IN THIS STUDY }
$$

Figure 1. Diagram of research steps. 


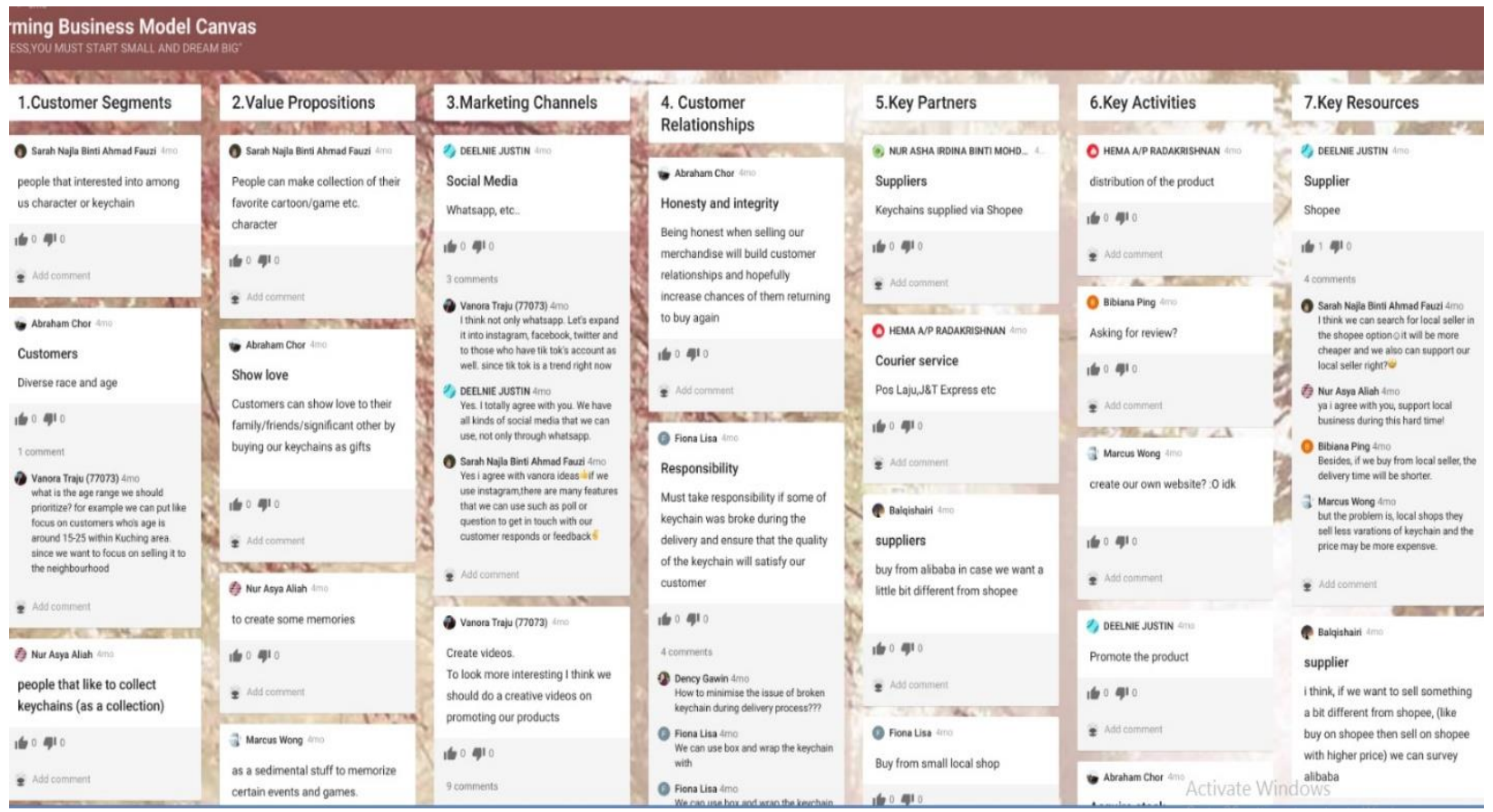

Figure 2. Students used Grid format to organise their wall Padlet

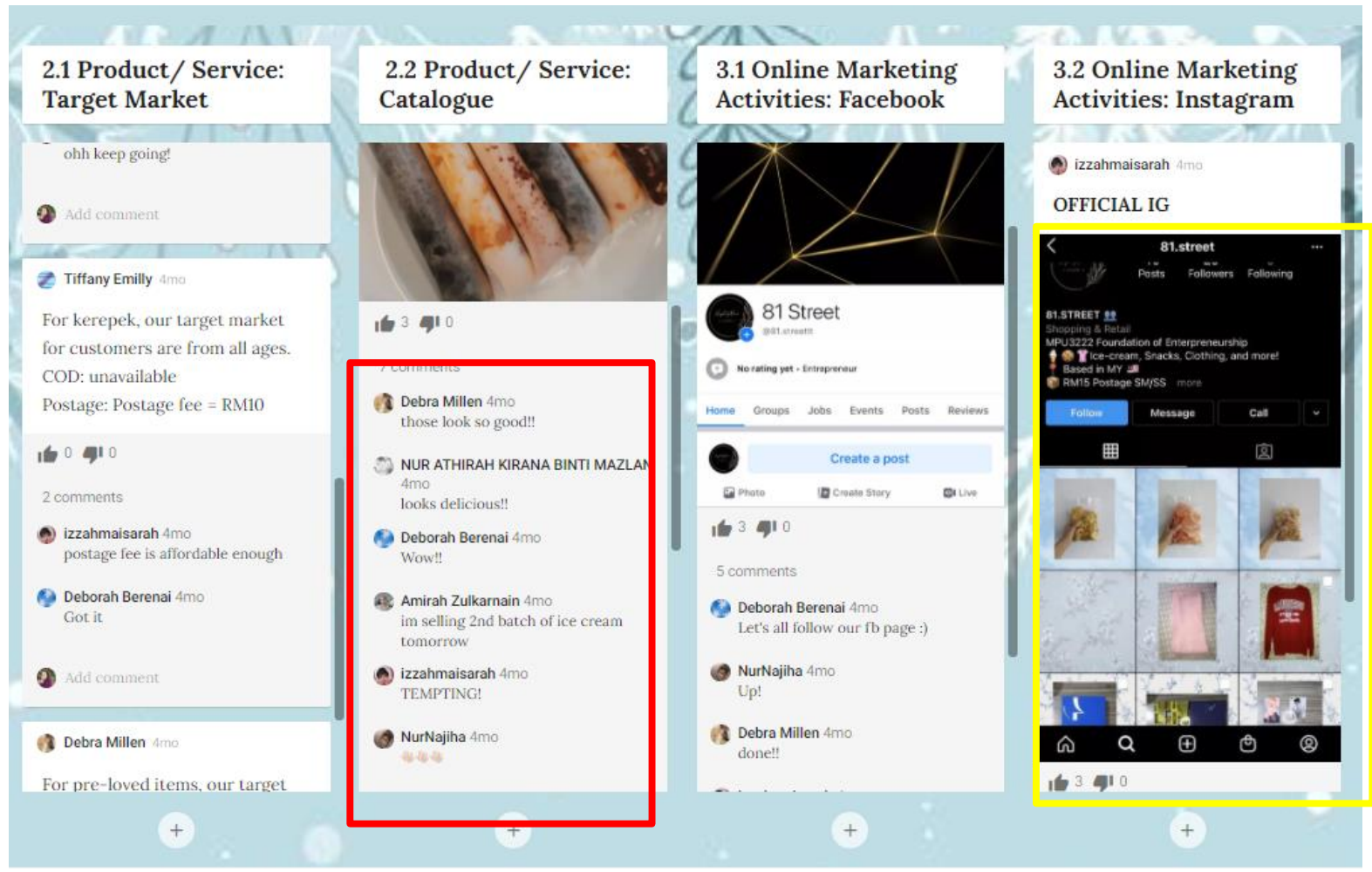

Figure 3. A comment box was modified as a chat platform to enable inter-group discussions (in red box). Highlighted contents were uploaded on walls as a reference across all groups (in the yellow box) 
Table 1. Dichotomous and trichotomy scale closed-ended questions

\begin{tabular}{|c|c|c|c|c|}
\hline No & Item & No & Yes & Maybe \\
\hline 1 & Is this your first time using Padlet & & & NA \\
\hline 2 & $\begin{array}{l}\text { Do you have internet connection problems } \\
\text { while having an online discussion using } \\
\text { Padlet? }\end{array}$ & & & NA \\
\hline 3 & $\begin{array}{l}\text { Do you prefer to use other online/ ICT tools } \\
\text { instead of Padlet when doing group } \\
\text { assignments? }\end{array}$ & & & NA \\
\hline 4 & $\begin{array}{l}\text { If the internet connection is good, do you still } \\
\text { want to use Padlet for online brainstorming } \\
\text { discussions and create portfolios? }\end{array}$ & & & \\
\hline
\end{tabular}

In addition, the frequency of postings and comments is recorded to determine the relationship between the behaviour in using Padlet and the actual learning performance evaluated at the end of the course. The Pearson's correlation coefficient, $r_{p}$, was used to detect the correlation between the number of posts and comments on Padlet walls and the students' written assignments and pitching presentation marks. The significance level was set at $\alpha=0.05$.

\section{FINDINGS}

\subsection{Participations}

Of the 88 students who enrolled in the course, 82 participated in the online survey. Forty-two of them are first time users using the Padlet. Respondents were asked whether they had internet connection problems while having an online discussion using Padlet. Fifty-nine of them said they did not have any internet problems, while 23 had issues connecting with Padlet. 


\subsection{The students' perception of using Padlet as a learning tool}

Two questions from the online survey relate to the students' perception of using Padlet as a learning tool. Table 2 shows that almost all respondents agreed that Padlet is a useful online tool for academic engagement purposes $(\mathrm{Q} 1: \mathrm{A}=61 \% ; \mathrm{SA}=36.6 \%)$, and to allow them to engage with their peers and lecturer at any time and any place (Q2: $A=54.9 \% ; \mathrm{SA}=39 \%)$.

Table 2. Analysis of students' responses to the use of Padlet as a learning tool. Data are presented in a percentage format

\begin{tabular}{|l|c|c|c|c|}
\hline \multicolumn{1}{|c|}{ Item } & \multicolumn{3}{|c|}{ Likert Scale } \\
\cline { 2 - 5 } & $\begin{array}{c}\text { Strongly } \\
\text { Disagree } \\
\text { (SD) } \\
\text { (D) }\end{array}$ & $\begin{array}{c}\text { Disagree } \\
\text { Agree (A) }\end{array}$ & $\begin{array}{c}\text { Strongly } \\
\text { Agree (SA) }\end{array}$ & \\
\hline $\begin{array}{l}\text { Padlet is convenient for academic } \\
\text { engagement purposes. }\end{array}$ & 0 & 0.02 & 61 & 36.6 \\
\hline $\begin{array}{l}\text { Padlet allows me to academically engage } \\
\text { with peers and my lecturer at any time } \\
\text { and any place. }\end{array}$ & 0 & 0.06 & 54.9 & 39 \\
\hline
\end{tabular}

\subsection{Padlet as an online tool for learner engagement and collaboration}

The quantitative data presented in Table 3 are derived from eight questions related to students' perceptions of using Padlet for engagement and collaboration. More than half of the participants agreed that Padlet helped them engage with their peers to complete their projects. Less than half of them disagreed with the usage of Padlet as a discussion platform. For the last question, more than $70 \%$ of respondents agreed $(\mathrm{SA}=29.3 \% ; \mathrm{A}=56.1 \%)$ to use Padlet as one of the online tools for any group assignments in future learning. 
Table 3. Analysis of students' responses at the use of Padlet as an online tool for learner engagement and collaboration. Data is presented in a percentage format

\begin{tabular}{|c|c|c|c|c|}
\hline \multirow[b]{2}{*}{ Item } & \multicolumn{4}{|c|}{ Likert Scale } \\
\hline & $\begin{array}{l}\text { Strongly } \\
\text { Disagree } \\
\quad \text { (SD) }\end{array}$ & $\begin{array}{l}\text { Disagree } \\
\text { (D) }\end{array}$ & $\begin{array}{l}\text { Agree } \\
\text { (A) }\end{array}$ & $\begin{array}{l}\text { Strongly } \\
\text { Agree } \\
\text { (SA) }\end{array}$ \\
\hline Group discussion via Padlet is a good idea. & 0 & 20.7 & 43.9 & 35.4 \\
\hline $\begin{array}{l}\text { Discussing project using Padlet is convenient for } \\
\text { me. }\end{array}$ & 1.2 & 20.7 & 47.6 & 30.5 \\
\hline $\begin{array}{l}\text { Padlet allows me to brainstorm and share ideas } \\
\text { for projects with team members. }\end{array}$ & 2.4 & 2.4 & 48.8 & 46.3 \\
\hline $\begin{array}{l}\text { My interaction with team members in Padlet was } \\
\text { clear. }\end{array}$ & 0 & 12.2 & 50.0 & 37.8 \\
\hline $\begin{array}{l}\text { My interaction with team members in Padlet was } \\
\text { understandable. }\end{array}$ & 0 & 7.3 & 51.2 & 41.5 \\
\hline $\begin{array}{l}\text { Interaction via Padlet helped me to be active in } \\
\text { group discussions. }\end{array}$ & 2.4 & 9.8 & 47.6 & 40.2 \\
\hline $\begin{array}{l}\text { It was easy for me to become skilful in } \\
\text { discovering information from team members via } \\
\text { Padlet. }\end{array}$ & 1.2 & 4.9 & 56.1 & 37.8 \\
\hline
\end{tabular}


In future, I will use Padlet in doing group assignments.

\begin{tabular}{|l|l|l|l|}
\hline 3.7 & 11.0 & 56.1 & 29.3 \\
\hline
\end{tabular}

\subsection{Padlet as an online tool to nurture students' soft skills}

The following questionnaire data presented in Table 4 are from three questions related to the students' perception of the Padlet use as an online tool to nurture students' soft skills. More than half of the respondents agreed that Padlet is useful in helping them to improve their soft ( $\mathrm{SA}=$ $30.5 \% ; \mathrm{A}=58.5 \%)$, team building $(\mathrm{SA}=28 \% ; \mathrm{A}=54.9 \%)$ and entrepreneurship skills $(\mathrm{SA}=20 \%$; $\mathrm{A}=59.8 \%)$.

Table 4. Analysis of students' responses at the use of Padlet as an online tool to nurture students' soft skills. Data are presented in a percentage format

\begin{tabular}{|l|c|c|c|c|}
\hline \multicolumn{1}{|c|}{ Item } & \multicolumn{3}{|c|}{ Likert Scale } \\
\cline { 2 - 5 } & $\begin{array}{c}\text { Strongly } \\
\text { Disagree } \\
\text { (SD) }\end{array}$ & $\begin{array}{c}\text { Disagree } \\
\text { (D) }\end{array}$ & $\begin{array}{c}\text { Agree } \\
\text { (A) }\end{array}$ & $\begin{array}{c}\text { Strongly } \\
\text { Agree } \\
\text { (SA) }\end{array}$ \\
\hline $\begin{array}{l}\text { I found that Padlet has effectively improved my } \\
\text { soft } \\
\text { skills fleadership, } \\
\text { communication, problem-solving, flexibility, } \\
\text { time management). }\end{array}$ & 1.2 & 9.8 & 58.5 & 30.5 \\
\hline $\begin{array}{l}\text { I found that Padlet has effectively improved my } \\
\text { team-building skills. }\end{array}$ & 2.4 & 8.5 & 54.9 & 28 \\
\hline $\begin{array}{l}\text { I found that Padlet has effectively improved my } \\
\text { entrepreneurship skills. }\end{array}$ & 2.4 & 13.4 & 59.8 & 20 \\
\hline
\end{tabular}




\subsection{Padlet as a student e-portfolio tool}

In Table 5, the quantitative data was derived from the three questions on perceptions of using Padlet as a student portfolio tool. More than half agreed that Padlet has helped organise their work $(\mathrm{SA}=51.2 \% ; \mathrm{A}=42.7 \%)$. Furthermore, most of them agreed that Padlet could be utilised to take meeting minutes $(\mathrm{SA}=45.1 \% ; \mathrm{A}=43.9 \%)$ and to create business portfolios $(\mathrm{SA}=50.0 \% ; \mathrm{A}=$ $46.3 \%)$

Table 5. Analysis of the use of Padlet as a student e-portfolio tool. Data is presented in a percentage format

\begin{tabular}{|l|c|c|c|c|}
\hline \multicolumn{2}{|c|}{ Item } & \multicolumn{2}{c|}{ Likert Scale } \\
\cline { 2 - 5 } & $\begin{array}{c}\text { Strongly } \\
\text { Disagree } \\
\text { (SD) }\end{array}$ & $\begin{array}{c}\text { Disagree } \\
\text { (D) }\end{array}$ & $\begin{array}{c}\text { Agree } \\
\text { (A) }\end{array}$ & $\begin{array}{c}\text { Strongly } \\
\text { Agree } \\
\text { (SA) }\end{array}$ \\
\hline $\begin{array}{l}\text { Using Padlet can make group works more } \\
\text { organised. }\end{array}$ & 0 & 6.1 & 42.7 & 51.2 \\
\hline $\begin{array}{l}\text { Using Padlet can replace meeting minutes. } \\
\text { Padlet is a great online/ ICT tool to create } \\
\text { business portfolios (e.g. Attach BCM, keeping } \\
\text { receipts, customers feedback) }\end{array}$ & 2.4 & 8.5 & 43.9 & 45.1 \\
\hline
\end{tabular}

\subsection{Padlet for remote discussion}

Students were asked whether they still want to use Padlet for online discussion activities and create portfolios if the internet connection is good. Twenty-seven respondents still wanted to use Padlet, while only two rejected the usage of Padlet. However, 53 respondents were not sure whether to use Padlet even the internet connection is good. Students were asked if they preferred to use other online/ ICT tools instead of Padlet for group project-based assignments in the following question. Thirty-six respondents still preferred to use Padlet for group assignments in future, but 41 opted to use other online/ ICT tools. 
The following question, the open-ended question, asked 41 respondents why they did not favour Padlet. From 41 statements given by the respondents, 12 stated their reasons for not choosing Padlet. Most of the reasons that technical factors and the way Padlet was used for online discussion activities. Since students were given the responsibility to plan their activities on Padlet as part of students' independent learning, some might have issues communicating and engaging effectively with their team members via Padlet. They mentioned Padlet "does not provide notification as other tools, causing other team members to lose track of the project progress", or their team members did not "react instantly" to any matter they were asked for. Besides, some of them were uncomfortable and not keen to participate in discussion activities using Padlet. In addition, a few reported that they had a "slow internet connection", and one of them was having a problem that his/ her laptop "is not compatible" with Padlet. Moreover, since all students subscribed to the free account, they realised Padlet was not as convenient as other tools, often used for similar functionalities. A free account would only allow each user to make three Padlet walls at any one time.

It was also interesting to obtain feedback about other online/ ICT tools or media the participants preferred when doing group assignments. Thirty-nine respondents have listed out online tools that they preferred to use for remote discussion. The most favorite tool used to communicate and engage was, WhatsApp $(n=24)$; the other tools include Telegram $(n=5)$; Microsoft Team $(n=5)$; Zoom ( $n=3)$; Discord $(n=3)$, Google Meet $(n=1)$ and Webex $(n=1)$. WhatsApp was picked as the most popular choice because it is the easiest to use and deemed "more convenient". The Whatsapp tool also does "not require more internet data". Besides, it has many features such as video calls which students can effectively get engaged by having a synchronous discussion, making a voice call, texting, sharing documents, and being notified with notification alerts; hence "can get direct responses from team members regarding group works".

In addition, to achieve their common goals in producing good business proposals and portfolio reports as well as power-point presentations, the participants used several online collaboration tools such as Google Docs $(n=10)$, Google Drive $(n=1)$, Google Slides $(n=1)$ as well as a web version of Microsoft Word $(n=1)$. Students used these collaboration tools to enable their remote teams to work on the same task synchronously and asynchronously. Google Docs, Google Slides, and Microsoft Word's web version allowed team members to view, edit, work simultaneously, and share those documents in Google Drive. One of the participants suggested using Sribblar, an online whiteboard collaboration, as an alternative to Padlet. Another suggested using Quora and Reddit to acquire knowledge and information from a crowd. These suggestions indicate an existing tendency among participants to explore various tools to complement their learning activities.

\subsection{Correlation analyses}

The Spearmen's coefficient correlation analysis of all the 15 Likert scale questions revealed the $r_{s}=-1$ at the 0,01 level (2 tailed). By usual standards, the relationship between these two variables $(\mathrm{SD}+\mathrm{D})$ and $(\mathrm{SA}+\mathrm{A})$ of the Likert scale would be considered statistically significant. In other words, the Correlation indicates a strong negative relationship between the two variables, which as one variable increases, the other tends to decrease. In this case, the SA+A for one item is fitted to coincide with SD+D for the same item. 
Pearson's correlation coefficient analyses (Table 6) revealed that the number of participations using Padlet and Business Model Canvas preparation is significantly correlated. Besides, the Correlation between participation and financial preparation is also significantly correlated. The other two correlations (idea validation and business portfolio) are not significantly correlated, due to using other applications besides Padlet.

Table 6. Pearson correlation coefficient $\left(r_{p}{ }^{2}\right)$ for the relation of assignments with students' participation using Padlet

\begin{tabular}{|c|c|c|}
\hline \multirow{2}{*}{ Assignment } & \multicolumn{2}{|c|}{ Correlation } \\
\hline & $\mathbf{r}_{\mathrm{p}}^{2}$ & $p$ \\
\hline Idea validation & -0.458 & 0.254 \\
\hline Business Model Canvas & -0.954 & $0.000^{* *}$ \\
\hline Financial & 0.720 & $0.044^{*}$ \\
\hline Business portfolio & 0.118 & 0.780 \\
\hline
\end{tabular}

\section{DISCUSSION}

This study was conducted to examine students' perceptions in using Padlet as a digital educational tool in the learning of the Foundation of Entrepreneurship course. The study is constructed to understand the impact of usage among participants on their project-based learning. Results from this study revealed that students' perceptions of Padlet were mostly positive despite some negative responses.

In this study, students were required to put all their ideas and information related to their business projects onto Padlet. They used Padlet as a "chat-board" which to allow them brainstorming ideas and strategise their business plans. These online engagement activities have resulted in extensive 
resources for them to use on their business plans. Even though some students did give ideas and information that may not be usable for their business plans, they managed to extract valuable primary ideas and information deposited on their Padlet walls. It shows that students have acquired decision-making skills, one of the critical skills for entrepreneurship (Shepherd et al., 2015). With Padlet's capability to support files in various formats and handle a considerable number of resources, the participants agreed that Padlet has helped them become organised. They also indicated that the use of Padlet had enhanced their soft skills (communication skills, teamworking skills), which contribute toward future tasks and goals.

During the experimental study, participants were also required to share their Padlet walls with their instructor. By doing this, they could receive direct feedback from their course instructor about their class tasks and subsequently learn their mistakes and improve before submitting their work. Therefore, Padlet can help in motivating the students to improve their work and learning. The results of this study are synonymous with a study conducted by Rashid et al. (2019). They discovered that the usage of Padlet enhanced students' motivation, interaction and collaboration when completing work. A study by Md Deni and Arifin (2019) also revealed that the students were inspired and managed to produce ideas just by learning from examples given by their teacher. Furthermore, some students probably visited the online marketing links of other groups, which were shared onto Padlet, as they wanted to see how the other groups did their online marketing strategies. It prompts students to have entrepreneurial curiosity (Jeraj \& Maric, 2013), positively driving them to improvise their marketing strategies.

Using Padlet in an entrepreneurship course can promote positive collaborative learning experiences based on the students' responses. In other words, Padlet is a suitable online tool to be used for any project-based learning activities. The analysis from the study aligns with Blumenfield et al. (1991) who proposed that it is crucial to choose the right online tools that can improve students' interest, contribute to various challenges, assist students to produce outcomes that represent students' understanding and encourage students to interact positively with one another. However, in this study, the students still preferred to use other online tools. It shows that positive perceptions of Padlet did not indicate that Padlet is a valuable and friendly tool for independent learning. It could be due to external factors related to the technical aspects and time restrictions due to workload from other courses (Ng 2007, An et al., 2009; Md Deni \& Zainal, 2017). Similar external factors were also identified from this study, as participants reported having difficulty assessing Padlet due to access disruptions, unstable internet connections, and the incompatibility of Padlet when running on their laptops. The issues emerged on the Padlet walls; students who experienced bad internet connections could not participate in the discussion activities using Padlet compared to those with better, reliable internet access and laptops.

Consequently, these technical issues caused some participants to feel less motivated to use Padlet for remote discussion. As a workaround, they have opted to use other tools that only require low bandwidth, such as WhatsApp or Telegram, to engage with their team members. Those two social messaging applications have the notification feature, which can instantly alert the team members to respond with any matters regarding their projects. However, the shortage of these two chatting applications is that students need to scroll down all chat conversations from top to bottom to 
retrieve specific information needed for their projects. Therefore, Padlet can be an alternative application for them to keep information organised.

In this study, students were also allowed to use other online tools that they were comfortable with. They used Google Docs, Google Drive, Google Slides, Google Meet, Zoom, Discord, Webex, and Microsoft Word's Online version. The tools have some features that Padlet does not have. For example, Google Docs is a tool that can facilitate collaboration by enabling students in various locations to work concurrently but independently on the same artefact (ÓBroin \& Raftery, 2011). In this study, students used Google Docs to produce business proposals and portfolios. The combination of all these online tools facilitated them to complete their assignments well. It indicates that other suitable tools shall be used with Padlet to facilitate students' project-based learning, especially during this pandemic. Additionally, any user-friendly learning tools shall be used together with reliable communication infrastructure (Huang et al., 2020).

This study also unearthed one student's discomfort in using Padlet when asked to participate in online discussions. Other studies reported the same phenomenon in which students felt uncomfortable with the openness of the platform and hence developed reluctance to participate and use Padlet (An et al., 2009; Murphy \& Fotner, 2014; Ahmed et al., 2016). Besides, as all Padlet activities were arranged as part of project-based learning, students who were not self-regulated and lack autonomy had problems engaging with other team members. Therefore, some pedagogical modifications are required to actively motivate students to participate and use Padlet for projectbased learning activities. For example, the level of participation by instructors shall be reasonable; not too little, or not too many participations (Dennen, 2005; Murphy \& Fotner, 2014). Another way is by providing a scoring rubric for discussion to students during the introductory course (Murphy \& Fotner, 2014). To develop a good discussion rubric that can assess the quality of posts, instructors shall include specific criteria such as students' reading materials, writing of ideas, and overall engagement in discussion activities. By doing so, students will be motivated to participate in the online discussions, as they will be driven to obtain a maximum point for posting as much as possible in Padlet.

\section{CONCLUSION}

Padlet can be applied as a collaborative tool to facilitate project-based learning in the Entrepreneurship course. However, it shall be used with other online tools to overcome technical flaws because it depends on a good internet connection. Even though by only using a Padlet nonpaying basic plan, each student could only have three Padlet walls, this limitation could be solved as few group members still have free walls. Besides, less face-to-face communication among the instructor and students while using the Padlet could cause misunderstanding or receiving erroneous information from both sides. In addition, to make students actively participate in the online discussion, instructors shall design effective pedagogical strategies to support project-based learning from online discussion.

The present study focused on using Padlet as a tool for remote learning during the Covid-19 pandemic. Remote learning is experimental, specifically in the teaching of contents and skills 
related to Entrepreneurship. The study investigated the maiden attempt to create learning spaces virtually, and there are still many aspects about remote learning and the nature of Entrepreneurship that need to be explored. Conducting virtual project-based learning has its own sets of challenges, and educators should try to understand the integration of tools and taught content to make teaching effective. Experimentation of various collaborative learning pedagogies should ensue to enable educators to make better decisions about the approach and strategies that best fit their students and the taught content.

\section{ACKNOWLEDGMENTS}

This research did not receive any specific grant from funding agencies in the public, commercial, or not-for-profit sectors. The author would like to thank Dr Ling Teck Yee for encouraging and guiding the writing of the manuscript. The author is also grateful for the opportunity provided by the Centre for Applied Learning and Multimedia (CALM) to participate in its Postgraduate Diploma in Higher Education Teaching and Learning (PgDip HETL) programme. The manuscript was prepared as the final requirement for graduation from the programme.

\section{REFERENCES}

Abu-Saifan, S. (2012). Social entrepreneurship: Definition and boundaries. Technology Innovation Management Review, 2(2), 22-27. https://doi.org/10.22215/timreview/523

Ahmad, S. Z., \& Xavier, S. R. (2012). Entrepreneurial environments and growth: Evidence from Malaysia GEM data. Journal of Chinese Entrepreneurship, 4(1), 50-69. https://doi.org/10.1108/17561391211200939

Ahmed, A. M., AbdelAlmuniem, A., \& Almabhouh, A. A. (2016). The current use of Web 2.0 tools in University Teaching from the perspective of faculty members at the College of Education. International Journal of Instruction, 9(1), 179-194. doi:10.12973/iji.2016.9114a

An, Y. J., Aworuwa, B., Ballard, G., \& Williams, K. (2009). Teaching with Web 2.0 technologies: Benefits, Barriers and Best Practices. AECT Annual Proceedings, 1, 1-6.

Aneros, N. (2020 December). Japanese Learners' Perception of using Padlet in Japanese composition (Sakubun) skills. In 4th International Conference on Language, Literature, Culture and Education (ICOLLITE 2020) (pp. 499-505). Atlantis Press. doi:10.2991/assehr.k.201215.078

Blumenfeld, P. C., Soloway, E., Marx, R. W., Krajcik, J. S., Guzdial, M., \& Palincsar, A. (1991). Motivating project-based learning: Sustaining the doing, supporting the learning. Educational Psychologist, 26(3-4), 369-398. https://doi.org/10.1080/00461520.1991.9653139

Botha, M. (2010). A project-based learning approach teaches entrepreneurship to a large group of undergraduate students in South Africa. Education as Change, 14(2), 213-232. https://doi.org/10.1080/16823206.2010.522059 
Delacruz, E., Brock, D., Fuglestad, T., Ferrell, K., Huffer, J., \& Melvin, S. (2014). Teaching art in the age of social media: Firsthand accounts of five technology-savvy art teachers. Texas Trends, 1, 61-66. https://www.taea.org/TAEA/Docs/2014/TRENDS-2014.pdf.

Dennen, V. P. (2005). From message posting to learning dialogues: Factors affecting learner participation in asynchronous discussion. Distance Education, 26(1), 127-148. https://doi.org/10.1080/01587910500081376

Dewitt, D., Alias, N., \& Siraj, S. (2015, 27-29 May). Collaborative learning: Interactive debates using Padlet in a higher education institution. In International Educational Technology Conference (IETC 2015), Istanbul, Turkey.

Dwerryhouse, R. (2001). Real work in the 16-19 curriculum: AVCE business and young enterprise. Education and Training, 43(3), 153-161. https://doi.org/10.1108/EUM0000000005460

Fageeh, A. I. (2011). EFL learners' use of blogging for developing writing skills and enhancing attitudes towards English learning: An exploratory study. Journal of Language and Literature, 2(1), 31-48.

Frank, M., Lavy., I., \& Elata. D. (2003). Implementing the project-based learning approach in an academic engineering course. International Journal of Technology and Design Education, 13, 273-88. https://doi.org/10.1023/A:1026192113732

Fuchs, B. (2014). The writing is on the Wall: Using Padlet for whole-class engagement. LOEX Quarterly, 240(4), 7. https://uknowledge.uky.edu/libraries_facpub/240

Ghazali, N.M., \& Anuar, A. (2020). Asynchronous online learning activities in the research methodology class. InSight Bulletin, 31, 25-28.

Gibb, A. (1999). Can we build effective entrepreneurship through management development? Journal of General Management, 24(4), 1-21. https://doi.org/10.1177/030630709902400401

Harian, B. (2006), Pendidikan keusahawanan di IPTA, Trans: Entrepreneurship Education in Public University, 6 June.

Hebert, R. F., \& Link, A. N. (2009). A History of Entrepreneurship. Routledge. doi:10.4324/9780203877326

Jamaluddin, R., Zakaria, A., Jusoh, R., \& Kamis, A. (2019). Nurture students' soft skills through project-oriented problem-based learning approach in Siswa@ Fesyen. KnE Social Sciences, 3(12), 208-222. https://doi.org/10.18502/kss.v3i12.4087

Jeraj, M., \& Marič, M. (2013, March 20-22). Entrepreneurial curiosity-The New Construct. In High potentials, lean organisation, internet of things: Proceedings of the 32nd International Conference on Organizational Science Development (pp. 289-298), Portoroz, Slovenia. 
Kolb, D. A., Boyatzis, R. E., \& Mainemelis, C. (2001). Experiential learning theory: Previous research and new directions. Perspectives on Thinking, Learning and Cognitive Styles, 1(8), 227247.

Korkealetho, K., \& Siklander, P. (2018, June). Enhancing engagement, enjoyment and learning experiences through gamification on an English course for health care students. In Seminar. net (Vol. 14, No. 1, pp. 13-30).

Matlay, H. (2005). Researching entrepreneurship and education: Part 1: What is entrepreneurship, and does it matter? Education and Training, 47 (8/9), 665-77. https://doi.org/10.1108/00400910610710119

Md Deni, A. R., \& Zainal, Z. I. (2017). 'I love it, but I don't use It': Students' perceptions on the use of Padlet as an Educational Tool for Learning. Turkish Online Journal of Educational Technology, Special Issue for the International Educational and Technology Conference (IETC 2017), 7-13.

Md Deni, A. R., \& Arifin, A. (2019). Using padlet for project-based learning in documentary filmmaking. ACM International Conference Proceeding Series, November 30-35. https://doi.org/10.1145/3371647.3371648

Murphy, C. A., Fortner, R. A., \& Mukherjee, P. (2014). Impact of instructor intervention on the quality and frequency of student discussion posts in a blended classroom. MERLOT Journal of Online Learning \& Teaching, 10(3), 337-350.

Musa, F., Mufti, N., Latiff, R. A., \& Amin, M. M. (2012). Project-based learning (PjBL): Inculcating soft skills in the 21st-century workplace. Procedia-Social and Behavioral Sciences, 59, 565-573. https://doi.org/10.1016/j.sbspro.2012.09.315

Nadeem, N. H. (2019). Students' perceptions about the impact of using Padlet on class engagement: An Exploratory Case Study. International Journal of Computer-Assisted Language Learning and Teaching, 9(4), 72-89. https://doi.org/10.4018/978-1-7998-8047-9.ch095

$\mathrm{Ng}, \mathrm{KC}$ (2007). Replacing face to face tutorials by synchronous online technologies- Challenges and pedagogical implications. International Review of Research in Open and Distance Learning, 8(1). https://doi.org/10.19173/irrodl.v8i1.335

ÓBroin, D., \& Raftery, D. (2011). Using Google Docs to support project-based learning. AISHEJ: The All Ireland Journal of Teaching and Learning in Higher Education, 3(1).

Othman, M. R. (2020). E-learning during Movement Control Order: A learning experience. InSight Bulletin, 31, 16-19.

Rashid, A. A., Yunus, M. M., \& Wahi, W. (2019). Using Padlet for Collaborative Writing among ESL Learners. Creative Education, 10(03), 610-620. https://doi.org/10.4236/ce.2019.103044 
Rathakrishnan, M., Ahmad, R., \& Choi, L. J. (2018). Padlet online discussion in enhancing students' macro Critical Thinking Skills. International Journal of Latest Research in Humanities and Social Science, 1(03), 121-126.

Rethinasamy, S., \& Ramanair, J. (2020). Teaching and learning during “Old Normal” and "New Normal": Modifications, justifications and Lessons Learnt. InSight Bulletin, 31, 45- 53.

Samaranayake, P. N. (2020). Student-centered learning with technology. Retrieved from https://www.researchgate.net/publication/338633241_Student-

centered_learning_with_technology

Scager, K., Boonstra, J., Peeters, T., Vulperhorst, J., \& Wiegant, F. (2016). Collaborative learning in higher education: Evoking positive interdependence. CBE-Life Sciences Education, 15(4), ar69. https://doi.org/10.1187/cbe.16-07-0219

Shepherd, D. A., Williams, T. A., \& Patzelt, H. (2015). Thinking about entrepreneurial decision making: Review and research agenda. Journal of Management,41(1), 11-46. https://doi.org/10.1177/0149206314541153

Smith, P. (2001). Action learning and reflective practice in project environments that are related to leadership development. Management Learning, 32(1), 31-48. https://doi.org/10.1177/1350507601321003

Spearman's Rho Calculator (2021, July 29). Retrieved from https://www.socscistatistics.com/tests/chisquare2/default2.aspx.

Stannard, R. (2015). English teaching professional. Web-watcher, 97, p.67.

Weller, A. (2013). The use of Web 2.0 technology for pre-service teacher learning in science education. Research in Teacher Education, 3(2), 40-46. https://doi.org/10.15123/uel.85w24

Zhi, Q., \& Su, M. (2015, October). Enhance collaborative learning by visualising the process of knowledge building with Padlet. In 2015 International Conference of Educational Innovation through Technology (EITT) (pp. 221-225). IEEE. doi: 10.1109/EITT.2015.54 